DOI: $10.17516 / 1997-1370-0610$

УДК 75.03

\title{
Architectural Space in the Paintings by Vincent van Gogh
}

\author{
Yuliya N. Avdeeva, Kseniya A. Degtyarenko, \\ Maria A. Kolesnik, Natalia P. Koptseva*, \\ Daria S. Pchelkina and Anna A. Shpak \\ Siberian Federal University \\ Krasnoyarsk, Russian Federation
}

Received 02.05.2020, received in revised form 05.06.2020, accepted 12.06.2020

\begin{abstract}
The article presents an overview of the basic conceptual post-impressionism principles to identify the artistic and sociocultural context of the works by Vincent van Gogh, and the published researches of paintings by Van Gogh, manifesting a diversity of approaches to the artistic heritage of the painter. The authors of the article analyse three pieces by Vincent van Gogh created in 1888: Bedroom in Arles, Interior of a Restaurant in Arles, and The Night Café. Belonging to the same period, these paintings were selected to study the way van Gogh translated psychological states and represented a subjective picture of the world through building an illusive architectural space. The article presents the results of the philosophic and art analysis of the given works depicting personal and public spaces, and a conclusion on the significance and role of the interior genre in the art of Vincent van Gogh is made.
\end{abstract}

Keywords: van Gogh, painting, post-impressionism, art work, tragedy, epistolary heritage, symbolic capital of the painting, interior, internal architectural space, composition.

Research area: theory and history of art, theory and history of culture.

Citation: Avdeeva, Yu.N., Degtyarenko, K.A., Kolesnik, M.A., Koptseva, N.P., Pchelkina, D.S., Shpak, A.A. (2020). Architectural space in the paintings by Vincent van Gogh. J. Sib. Fed. Univ. Humanit. Soc. Sci., 13(6), 838-859. DOI: 10.17516/1997-1370-0610.

(C) Siberian Federal University. All rights reserved

* Corresponding author E-mail address: decanka@mail.ru ORCID: 0000-0001-8194-7869 (Kolesnik); 0000-0003-3910-7991 (Koptseva); 0000-0002-2948-8762 (Shpak) 


\section{Conceptual principles of post-impressionism and its role in modern art}

Many art researchers including American art historian John Rewald considered post-impressionism to begin from the last impressionist exhibition in 1886 known as the first manifestation of neo-impressionists, and the publication of Jean Moréas's Symbolist Manifesto in the French Le Figaro newspaper in the same year (Chudov, 2018; Stoian, 2015). This stage came to an end at the turn of the centuries, resulting in the emergence of cubism, which was the starting point for modern art development. Speaking about the reasons that caused the emergence of symbolism, the leader of the symbolists, French poet Stéphane Mallarmé (1842-1898) emphasized the lack of stability in the society to give a start to stable art, the blurred social borders that disturbed the minds and entailed individualization in art (Illouz, 2005). Much later, French researcher Jean-Nicolas Illouz (1964-) also noticed that the complex socio-political situation in France in the late $19^{\text {th }}$ century, the dramatic process of republic development, made an impact on the development of French literature (Illouz, 2005).

Post-impressionism is the stage that followed impressionism, embracing artists working in different styles and under different concepts, who had their own way in art but were exposed to the direct impact of the impressionists, including the palette, technique, composition solutions etc. Unlike the impressionists who focused on observation of nature and depiction of a miraculous moment happening here and now, the late $19^{\text {th }}$ century's painters believed that the initial creative impulse was an idea embodied in the surrounding nature, and the main role in it had to be played by imagination, expression of their own contemplations and worldview (Koptseva et al., 2018; Avdeeva et al., 2019; Amosova et al., 2019; Koptseva et al., 2017). In their creative endeavours, the post-impressionists transformed the impressionist heritage, but still held on to its revolutionary ideas of art going beyond the academic notions, expanding the borders of visual perception.

The interest to the viewers' perception and optical effects continued developing in the works of post-impressionists (Georges Seurat, Paul Signac, Henri Edmond Cross, Lucien Pissarro etc.), but found some scientific grounds, such as the psychophysiological features of colour perception, colour theory of Michel Chevreul, Ogden Rood, Hermann von Helmholtz and others, and optic discoveries (Veimarn, 1965). Working in the genres of landscapes and still-life paintings, Paul Cézanne attempted to reinterpret the diversity of life forms in the framework of stereometrics, the contrast confrontation of shape and colour. Paul Gauguin turned to the symbolist program developed in French literature of that time, and withdrew from working on the viewers' impression of the piece, giving the main role to the conceptual content enveloped in the mystery of the past. The specificity of poster art takes origins from the works of Henri de Toulouse-Lautrec, who focused on psychologic expression, dynamic moments in the lives of his characters presented through expressive and grotesque forms. The art of Vincent van Gogh with its unique emotional and expressive language of the author, presented the problem of spirituality and moral in the contemporary person, the state of the surrounding world and the artist's own emotional world outlook.

Translating the spirit of its time, the establishment of new society, reinterpretation of values, and search for new meanings, post-impressionism promoted the development of the artistic culture of the turn of the $19^{\text {th }}-20^{\text {th }}$ centuries and served as a precursor for such modern art trends as fauvism, expressionism, cubism, symbolism, modern painting, poster art etc.

John Rewald also draw a parallel between post-impressionism and various art trends of the late $20^{\text {th }}$ century, such as post avant-garde and post-modernism. The main artists of the late $19^{\text {th }}$ century being the main trendsetters in the art of the coming century and modern art as a whole, are: Vincent van Gogh, Paul Gauguin, George-Pierre Seurat, Paul Cézanne, Henri de Toulouse-Lautrec, Henri Rousseau.

\section{Classical and modern studies of the art of Vincent van Gogh}

The interest of researchers towards the works of Vincent van Gogh, as well as recogni- 
tion of his art, gained momentum long after his death. The majority of the studies were written in the early $21^{\text {st }}$ century. Despite the common idea of the artist as an unhinged and a mentally ill person, modern researchers recognize his unique, consistent, committed character. Van Gogh amazes by his persistence in labour; he believed that this is not personal happiness that is the aim of one's existence, but continuous creative work and desire to leave a great heritage. He was convinced that it is not talent, but hard labour that makes a great artist. He continued working regardless of blows of circumstances and disapproval of his art by the contemporaries. Van Gogh had been insisting on his point of view and his opinion of art throughout his life. For him, painting was more than a purpose and mission of his life, it was life itself, the life he did not just portray, but lived every moment of it in his own way.

Studying the life and works of the great painter, the researchers elaborate on various aspects the studies: the controversial moments of biography and periods in work, the tragic motives of his life and painting, the specific painting techniques and symbolism, the contribution in further art development, cultural response to the works by his contemporaries (the dialogue of cultures), the Japanese influence on the works by Van Gogh, specificity of each painting period and analysis of different pieces of art.

The first article about the artist titled "The Isolated Ones: Vincent van Gogh" was written by young writer Albert Aurier back when the artist was alive. In the article, Aurier revealed the dualistic nature of Van Gogh's personality; being a great artist committed to painting, he was a passionate believer and a dreamer living in his beautiful ideas, utopias, and dreams. An adherer of symbolism, Aurier eagerly listed this artist among symbolists and wrote: "No doubt, like all the painters of his race, he is very conscious of material reality, of its importance and its beauty, but even more often, he considers this enchantress only as a sort of marvellous language destined to translate the Idea". However, in his response to this article, Vincent himself objected. He wrote that the author of the article had glamorized his image to make it fit his ideals and presented him as a romantic lonely genius. In a letter to his brother, Van Gogh wrote: "But the truth is so dear to me, trying to create something true also, anyway I think, I think I still prefer to be a shoemaker than to be a musician, with colours" (Van Gogh, 2018). He did not see himself as an isolated person in what he did; he thought he was in line with many others, though did not play a leading part in either society or art.

Interestingly, earlier studies written in the last decades of the $20^{\text {th }}$ century are of psychoanalytic nature and mostly belong to foreign researchers. Among the most commonly studied, and, importantly, doubtful and controversial questions there are the issues of psychopathologies the artist suffered from and the influence they made on his painting (Rahe,1990; Morrant, 1993; Lemke, Lemke, 1994; Blumer, 2002); xanthopsia and domination of yellow tones (Arnold, Loftus, 1991); addictions (Lee, 1981; Berggren, 1997) and suicidal inclinations of the painter (Mehlum, 1996; Montejo Gonsalez, 1993); the conflict with Gauguin and its consequences (Runyan, 1981); the anguish he suffered, branded with the "mark of shame" by the society (Benezech, Addad, 1997). Generally, this period is also distinctive with a number of works focused on the life and painting of the artist (Stoun, 1988; Uolleis, 1998).

For the early $21^{\text {st }}$ century, it is typical to speak of Van Gogh as a great painter who had left a unique, priceless heritage both in art and beyond. In the community of researchers and artists, we find less and less one-sided judgements of him as an unrecognized self-professed, or a rejected martyr suffering from a mental illness. There are more researchers introducing the life and work of Van Gogh from a different perspective: N.A. Dmitrieva (Dmitrieva, 1984), H. Perruchot (Perruchot, 1987), E. Weissman (Weissman, 2008), M. Gordeeva (Gordeeva, 2009), A.V. Golenkov (Golenkov, 2011), M.M. Drobysheva (Drobysheva, 2014), N. Heinich (Heinich, 2014), N.V. Kuzova (Kuzova, 2015), A. Savichev (Savichev, 2016), E. Gordeeva (Gordeeva, 2017), O.Iu. Zharina (Zharina, 2019).

A study by Ia. Beloshapkina (Beloshapkina, 2013) analysing the main features of Van 
Gogh's painting and the milestones of his life is of special interest. The author remarks that the principal expression and atmosphere-creating tool for Van Gogh was the colour. Van Gogh believed that a colour could reveal the soul of a character; every colour bore a deep symbolic meaning for him. Moreover, the painter contemplated over the psychological properties of colours and made up a system of his own, adopting the experience of the best colourists of the past. Beloshapkina also studied the motives and drivers of Van Gogh's creativity, and among the most powerful ones she mentioned commiseration and sympathy. Every piece carries a piece of the painter's soul: "...the closer to perfection the painting was, the more emotionally drained was the artist. Life was slowly slipping away from Vincent, flowing into his paintings".

The personality of Van Gogh was the object of research carried out by A.S. Filippova (Filippova, 2014), who made an attempt to draw a psychological portrait of the artist. She pointed out that Van Gogh should not be biased; his life was controversial and paradoxical. Though not naturally gifted, he became a great painter; not a talented speaker, he wrote astonishing letters to his brother, and today they are acknowledged as literary heritage. It is emphasized that Van Gogh was reaching out to people, willing to be heard and understood, but in the majority of cases he was rejected and avoided. The reason was his unwillingness to play the imposed social roles or to live up to someone's expectations, to blindly fulfil the instructions of his customers or to follow any trends of fashion due to the humanism ideas he preached. Filippova also noticed that several years after Van Gogh's death one venturous German man promoted the publishing of pseudoscientific monographs of the life and work of the artist, intentionally distorting the facts. The painter was presented as a mentally disturbed, careless sentimentalist, an outcast, a deeply miserable person who found himself in the circumstances he could not change. Filippova criticized this position, proving that Van Gogh was a pragmatic, industrious and resolute man, thoroughly planning every step he made.
E. Murina approached the analysis of works by van Gogh in an extremely diligent manner in her large theoretical work (Murina, 1978). She pointed out that it is not the historical and artistic, but the personal aspect that should be emphasized studying the works of the painter: it should be the "social tragedy of an innovator destined for misunderstanding and death". Later, the moral authority of this "painter person" promoted both the popularization of Van Gogh's artistic discoveries and the victory of new painting as a whole. Moreover, it highlighted the so-called psychological phenomenon, the painter's continuous meditation on his own life, himself and his activity. It shed new light over the unique personality of the painter and the originality of paintings by Van Gogh who, as a deeply spiritual person, created himself and built his own life, aware of not fitting in the surrounding world.

Modern researchers also focus on the unique techniques of painting and graphics, symbolism, and ontological status of Van Gogh's art. For instance, E.R. Kotliar and F.S. Emiruseinova (Kotliar, Emiruseinova, 2017) analyse the artist's brandmark oil painting technique, the individual stroke manner his paintings are recognized from. Moreover, the authors draw a parallel between the content of the paintings and the ideas of humanism manifested in the shapes and colour solutions. A.A. Ievleva and S.A. Khrapugina (Ievleva, Khrapugina, 2019) provided a detailed description of the painting technique, peculiarities of the colour solutions, attempted to explain the genre preferences of the painter and elaborated upon his epistolary heritage.

A.Iu. Puchkova (Puchkova, 2016) pointed out that the unique painting technique of Van Gogh was based upon his principal avoidance of the commonly accepted traditions, of the conventional and proportional imaging. Guided with his feelings and emotions, Van Gogh did not attempt to copy what he saw, but contributed his soul into every image he created. He depicted people in close communion with nature, avoiding smooth and graceful lines. He preferred abrupt and sharp lines, making people in his paintings resemble rocks. However, working on elements of nature, he tried to 
breathe life into them and to make them resemble human figures. This was the way he tried to translate the truth of the real life, which he internalized and expressed through art, without idealizing or brightening it up, inspiring people to do the new art he created.

N.S. Rodionov (Rodionov, 2017) studied the specificity of Van Gogh's painting in different periods of his life to monitor the changes and the factors that influenced the manner of the painter at every stage. D.N. Lugantsev (Lugantsev, 2017) turned to the specificity of Van Gogh's graphics and analysed a number of graphic works of the author to conclude that they were just as impressive as the oil paintings. The technique and artistic manner of the painter have been also considered by E. Dichenko (Dichenko, 2015), A. Kas'ianov (Kas'ianov, 2019).

S.A. Shul'ts (Shul'ts, 2018) took interest in the ontological status of art based on works by several painters. Speaking of Van Gogh, he turned to the research experience of M. Heidegger and H. Perruchot. According to them, a thing is initially constituted by art, not vice versa. This idea is clearly explained by Heidegger in his comments to Van Gogh's Shoes: "In Van Gogh's painting, truth happens. This does not mean that here something at-hand-before-us would be correctly depicted, but rather that in the becoming-manifest of the being-tool of the shoe-tool, being in its totality, world and earth in their counterplay, attain to unconcealedness". Therefore, art is the meaning-manifesting domain of the world's historical life, and its legislator is the artist himself. In the same context and in a similar manner, Perruchot elaborated on the idea of replacing people with things in works by Van Gogh: "In his Paris paintings, people are rare. If they are there, they are nothing but coloured shadows. The true life is somewhere else... Vincent paints a pair of his Borinage shoes, spotted with mud and worn by long walks; so precious to him, these shoes are presented like living beings, looking from the painting with human eyes" (Perruchot, 1987). Later, José Ortega y Gasset referred to this idea as dehumanization of art and called it a feature of modern art.
E. Sannikova (Sannikova, 2019) raised an interesting topic of art market, a meeting point of economics and culture. She promoted the ideas of David Throsby (Throsby, 2013) who developed the creative economy concept and supposed that there simultaneously existed a physical market of the works of art and a market of ideas. The physical market sets the economic value of art, while the market of ideas sets the cultural value. Sannikova applied the artistic production model to the works by Van Gogh to derive a new category of a "symbolic capital" that underlaid the economic price of an art work.

I.N. Sachkov and M.A. Chistiakov (Sachkov, Chistiakov, 2019) discovered three criteria to classify a process in art as a synergetic process. The subject matter of the study is the modern tendency of forming the evolutionary-synergetic paradigms to observe the emergence of self-organizing structures, the avalanche-like development process and the predictability of this process. The authors engaged themselves in searching for such synergy in the works by Van Gogh. They discovered and proved the synergetic nature of both his works and the paradigm of his acknowledgement and commercial success.

T.Iu. Plastova (Plastova, 2012) dedicated one of her works to studying the works by A.A. Plastov in the European culture context and concluded that his world outlook and the painting system were established under the influence of the paintings and epistolary heritage of Vincent van Gogh. The author found a number of parallels in the conceptual aspect of the paintings and stated that Van Gogh became a real inspiration for Plastov, making him feel free, powerful and confident in what he preached.

O.V. Stroeva (Stroeva, 2014) turned to the question of replicating images in modern culture, the topic that is gaining momentum in today's technical replicability era. She spoke about changing the perception of art as a phenomenon, about the destruction of uniqueness of cultural objects. Based on the exhibition titled "Van Gogh. The Canvas Come Alive" organized in Moscow, she illustrated the new status of art in the modern society. The de- 
veloping technologies change the art's way of being; now, the works of art can be a copy or a simulation, an everyday item or an entertainment facility. The author said that the category of beauty was losing its main property which is non-usability, and was turning into a mostly economic category.

Some studies are attractive with their unusual angle: if the past century's studies of culture and art were dominated by the idea of translation of new meanings from the European culture into the Russian one, some scholars today act by a reversal. For instance, the objective of study by Kharybina (Kharybina, 2019a) is the identification of the dialogic specificity of communication between the art cultures of Western Europe and Russia at the turn of the $19^{\text {th }}-20^{\text {th }}$ centuries, generating new concepts. Based on the essential and concept-building structures of Van Gogh and Leo Tolstoy, she discovered similar art concepts without a direct impact of Russian culture on the work by the European artist. The epistolary heritage of Van Gogh was concluded to be the most relevant source of influence. Among the common ideas, the author listed the inclination to perfect simplicity, Christian culture, image of nature as a source of harmony. In another study, Kharybina went through the dialogue of cultures, drawing parallels between the works by Van Gogh and Fyodor Dostoyevsky (Kharybina, 2019b). There are some other examples of contemporary studies of the culture parallelism involving the personality of the great artist, written by E.V. Rovenko (Rovenko, 2016), E.M. Kokurina (Kokurina, 2006), T.B. Trofimova (Trofimova, 2009).

And, indeed, today there is great number of works featuring the analysis of different works by Van Gogh: P. Harold, M.D. Blum (Harold, Blum, 1956), J. Margolis (Margolis, 2002), M.V. Balan (Balan, 2007; Balan, 2008), E.A. Dvoretskaia (Dvoretskaia, 2016), G.L. Groom (Groom, 2016), D.A Karimov, V.M. Serdiuchenko, P.S. Volkova (Karimov, Serdiuchenko, Volkova, 2018), E.A. Poliakova, T.V. Motova (Poliakova, Motova, 2019), E.A. Elina (Elina, 2019) and many others.

Therefore, starting from the second half of the $20^{\text {th }}$ century, there is an obviously growing interest to the life and creative heritage of Van Gogh expressed by both Russian and foreign researchers from various domains: art critics, psychologists and psychotherapists, culture researchers, philosophers, sociologists, medics and even musicians. We can see the nature of these studies change from the analysis of psychic disorders of the painter to the discovery of his unique artistic, literary and life heritage. Van Gogh became inspiration both for successor artists and simple viewers of his works. With his exceptional originality, will, persistence, and principal rejection of everything claimed to be correct, everything imposed and fashionable, he managed to demonstrate that every person is capable of leaving something great behind, even if he has not been gifted from the start.

\section{Philosophic and artistic analysis of paintings by Vincent van Gogh Bedroom in Arles (1888)}

The idea of the painting titled Bedroom in Arles (Fig. 1) came to Vincent van Gogh in 1888, as proven by letters addressed to his brother Theo van Gogh and painter Paul Gauguin. The letters also contain the first two drafts of the future work of art. There are two more known copies made by the painter himself in 1889 . All these drafts and paintings, quotes from letters describing the concept of the painting and the ways of bringing it to life should be doubtlessly used for the analysis of this piece.

The philosophic and art analysis of the painting appears relevant because traditionally it is considered from the position of attributes and the correctness of their arrangement (Brettell, 1986), the way they illustrate the ideas and methods of the artist's work (Van Tilborgh, 2012; Hendriks, 2011), acting as a ground for discussion of the illusory space created in the art works by Van Gogh (Ward, 1976; Heelan, 1983) and the colour palette he used (Saggio, 2011). These pieces were also interesting to the researchers as an example of a constant motive of interior in the paintings of the artist, bearing special emotional and psychological significance for him; moreover, it is also considered with respect to the biography of the author (Groom, 2016; Scillia, 2004). However, the 


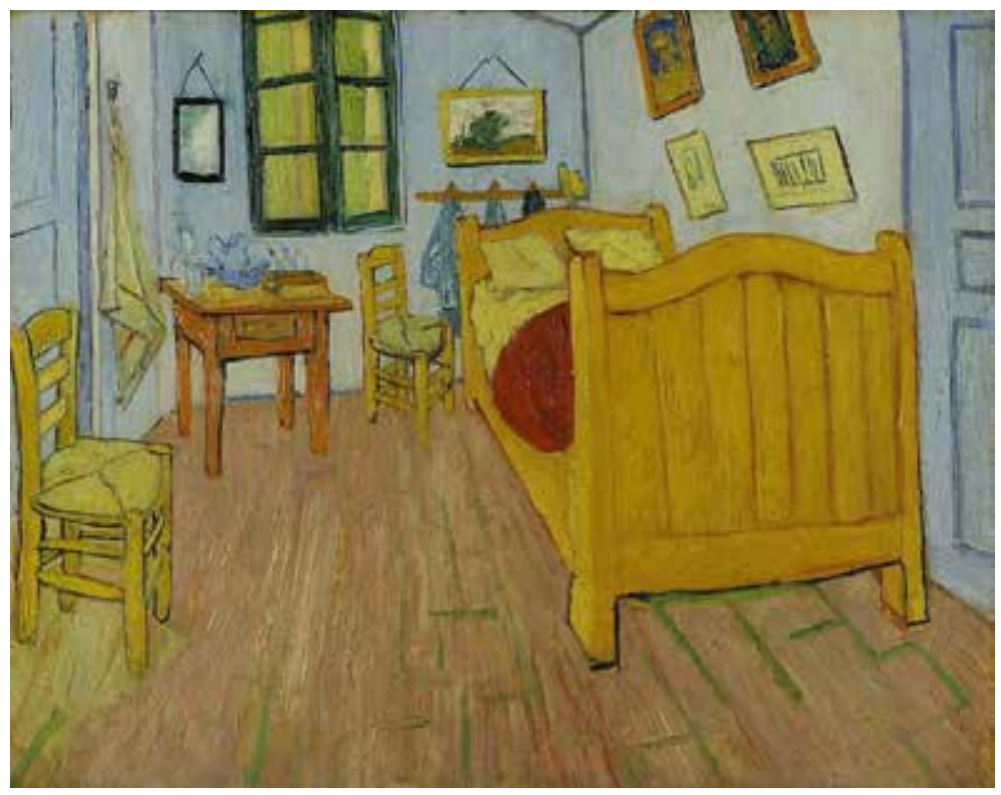

Fig. 1. Bedroom in Arles, Vincent van Gogh (1888) Canvas, oil, $72 * 90 \mathrm{~cm}$

purpose of this analysis is to identify the specificity of the architectural space in the works of the artist.

In one of the letters, Van Gogh wrote: "So I have gone over the canvas of my bedroom. That study is certainly one of the best..." (January 23, 1889 (Van Gogh, 2001: 610) which is a reason to suppose that Bedroom in Arles occupied a special place among other works of Van Gogh.

What is in the painting regularly mentioned in the letters of the painter? At first, it looks simple. The painting presents a small room with two doors, one on the left and one on the right, one window in the opposite wall, a low sloping ceiling, some furniture and some objects hanging on the walls.

The room is plain and ascetic, with minimum of things including a massive basic bed with two pillows and a blanket on it, two heavy wooden chairs, a toilet table with some toiletries on it, a mirror, a towel, a hanger with some clothes and a hat on it. Among the paintings on the walls, there is one landscape, two portraits, and two pencil drafts. In the centre of the canvas, there is nothing; some free and empty space is left in the middle.
The colours are also simple, based on the opposition of pure local colour spots with an obvious domination of warm yellow, brown, red, and olive tones in the lower part and colder blue and green tones in the upper part of the canvas, e.g. on the walls, doors and window frames. The colour composition is based on the theory of complementary colour pairs, particularly red and green, blue and orange, yellow and blue, as described in the letter from Van Gogh to Paul Gauguin: "I did, for my decoration once again, a no. 30 canvas of my bedroom with the whitewood furniture that you know. Ah, well, it amused me enormously doing this bare interior. With a simplicity à la Seurat. In flat tints, but coarsely brushed in full impasto, the walls pale lilac, the floor in a broken and faded red, the chairs and the bed chrome yellow, the pillows and the sheet very pale lemon green, the blanket blood-red, the dressing-table orange, the washbasin blue, the window green. I had wished to express utter repose with all these very different tones, you see, among which the only white is the little note given by the mirror with a black frame (to cram in the fourth pair of complementaries as well)" (1888), (Van Gogh, 2001: 798). Importantly, these colour pairs do 
not inflict a conflict but, on the opposite, highlight the essence of every colour, create a harmonic unity of the entire composition.

Now we may elaborate on the description of the objects filling the room: the bed stands out with its size and location. The footboard of the bed is very prominent, overlooking the viewer, appearing inaccessible as a high barrier. The bed itself is wooden (as the artist wrote, "whitewood"), massive and heavy, taking up almost a half of the room space. It stands in such a way that a part of it is protruding forward, to the entrance door. It creates an association with the idea of protection, security, a fortress, a guard. The bed keeps something soft, light, and warm; this is the way the linen looks with its red colour, warm and expressive. The pillows and the blanket embody the world of dreams, thoughts, fantasy, and imagination. Therefore, the essence of this item is securing the dream world from any foreign intruders.

The two chairs are similar to the bed in their character: both of them are also massive and heavy, made of simple, untreated materials. Both chairs are facing the bed; they are very similar, even the turn is the same. Just like the bed, these objects perform the function of protection, as the chair on the left is closing the entrance door. They look like two guards keeping something precious. The barrier they make is not insurmountable, but it is stated and it exists.

The toilet table is also simple and rudely made, with one drawer. On its top, we see subtle contours of the following things: two jugs, a bowl, a glass, a brush and two vials (in the next two versions, all the objects are more prominent and certain). All these items identify the space of cleanness and purification, associated with water. Before the table, there is a towel marking the entrance into the space of purification.

The mirror is what the examination of the walls begins with. We see a smooth transparent mirror that does not reflect anything, but has a potential of reflecting whatever appears before it. The mirror here is a clear, unadulterated surface.

The window with a green frame and greenish glass is slightly open, but it opens inside the room. The tall window makes a vertical line that stretches outside the painting. In the letter to his brother, having listed all the items of the room, the painter writes: "And that's all - nothing in this bedroom, with its shutters closed" (Van Gogh, 2001: 580). The window is also interpreted as a barrier protecting the room from the outer world. The painting models an isolated space. On the other hand, however, there is something that is ready to intrude; the window wings look about to open under the pressure of alien force.

The hanger is located right behind the headboard; there are three jackets and a hat in the corner. All the items have one and the same purpose: to cover and to protect. Judging from the colour, the hat should be a straw hat, which is also proven by a series of self-portraits of Van Gogh wearing such a hat. It looks burnt by the sun, saturated with its energy.

The pictures hanging around the walls indicate that this is not just a bedroom as a place of rest, but a bedroom as a workshop, a place where the artist's ideas are brought to life. It is interesting to know, which paintings found their place in this space.

In all three versions of the painting and in the draft attached to the letter to Gauguin, over the head of the bed there is a landscape painting; in the first and the second versions, there is a clear silhouette of a tree in the middle. In all the three versions, this is a picture of natural environment. The only exception is the draft addressed to brother Teo, where the artist formulates the idea of the future painting for the first time; there, over the head of the bed, is a portrait identified by researchers as Portrait of the Artist's Mother painted in October 1888. A portrait of the mother in this context could be interpreted as life-giving, creative power personified in a woman. The replacement of the portrait with a landscape painting means that the same powers find a more general interpretation, used to highlight rather the universal aspect than the individual aspect of the artist's personality.

On the right, in the lower row of the pictures, there are two pencil drafts, so vague that they are impossible to recognize. However, in the upper row there are two portraits, and in the 
first variant of the painting, the specialists identified them. These are portraits of the people Van Gogh was quite close friends with: the portrait of Eugène Boch (The Poet) and Paul-Eugene Milliet (The Lover). Eugène Boch was famous for supporting poor and unrecognized artists including Van Gogh himself. Paul-Eugene Milliet was known for handing him over a batch of Ukiyo-e woodcuts and paintings selected by Theo van Gogh. He also took painting classes with Van Gogh in exchange for taking some of his paintings to Paris to his brother. Therefore, these are the portraits of the people who were spiritually close to the painter, who helped and supported him.

Interestingly, in the next versions of the painting, there is a self-portrait of the author.

The analysis of the depicted items separately and in small groups demonstrated that the majority of them act as symbols of protection, shelter, patronage; another part of the depicted objects is associated with the idea of purification as a compulsory stage preceding the entrance into this space.

The mirror and the window together are a sign or revelation of the unrevealed (glass is a surface capable of reflecting and transforming things). The window glass in the painting is colourful, green behind the closed shutters. But generally, the space in the canvas may be described as illuminated, though the window, the only possible source of light, is closed with shutters from outside and would not let any light in. However, the logic of the physical world is broken here, and the gleams of olive colour, similar to those of the window glass, are found almost on all pieces of furniture. A coloured glass in a tall vertical window evoke the association with stained glass in a gothic church, contributing the air of sacredness to the entire picture, and highlighting the reminiscence to ablution similar to that done in religious cults, in an actual or symbolic form.

Another important part of the general composition is the focus of the viewer's attention on the head of the bed achieved by several means; first of all, this is the vanishing point of many lines, and the line of the clearly drawn corner stretches to the bed leg edge, bringing out the composition axis, and dividing the illusive space of the painting into two parts almost through the centre of the canvas. It can be said that the entire space is built around this axis (Fig. 2). The focus of attention on the head of the bed is especially important, because this is the thinking centre (over the head of the bed,



Fig. 2. Bedroom in Arles, Vincent van Gogh (1888) 
touching on the composition axis, there is the image of the hat, which also contributes to the idea of the domination in the room space). Therefore, the bed is not just a piece of furniture; this is a symbol of a place serving as the source of all creative ideas and dreams that are literally brought into life in the works hung over the bed and around the room.

As we have mentioned above, the chairs in the picture have a lot in common. Both of them find themselves in an interaction with the other pictured items, as though structuring and arranging a space for conversation. However, for the chair standing by the bed, this interaction is more obvious, for it makes a dialogue with the items reflecting the personality of the man living in the room, the one who sees a special meaning in bringing his dreams into a tangible form.

It is different for the second chair standing by the entrance into the illusive space of the room. The vanishing point of the perspective lines drawn through this object lies in the narrow opening between the window wings (Fig. 3). This reveals another important centre of the composition. Keeping in mind that the window indicates a sacred place, this makes a dialogue with supernatural powers.
The illusive architectural space built by Van Gogh is intended to model the world of the artist, which accepts only a person with a pure heart, capable of treating all the components of this world with attention and care. It is also important that the world of creation, ideas, and fantasies of the artist, seeming to be robust and simple, is extremely fragile. This is more than a room, but a place of sacrament, where all the common routine items can transform into something different, something sacred.

\section{Night Café, Vincent van Gogh (September 1888)}

The work of art titled The Night Café is commonly analysed in the historical context, as one of the works painted during Van Gogh's stay in Arles (Najfi, 2016), or studied from the perspective of the colours, as this was the aspect frequently mentioned by the artist himself in letters to his brother, Theodor Van Gogh (Van Gogh, 2010).

The Night Café is often defined as a continue of The Sower: "The idea of the sower still continues to haunt me. Exaggerated studies like the sower, like the night café now, usually seem to me atrociously ugly and bad, but when I'm moved by something, as here by this lit-

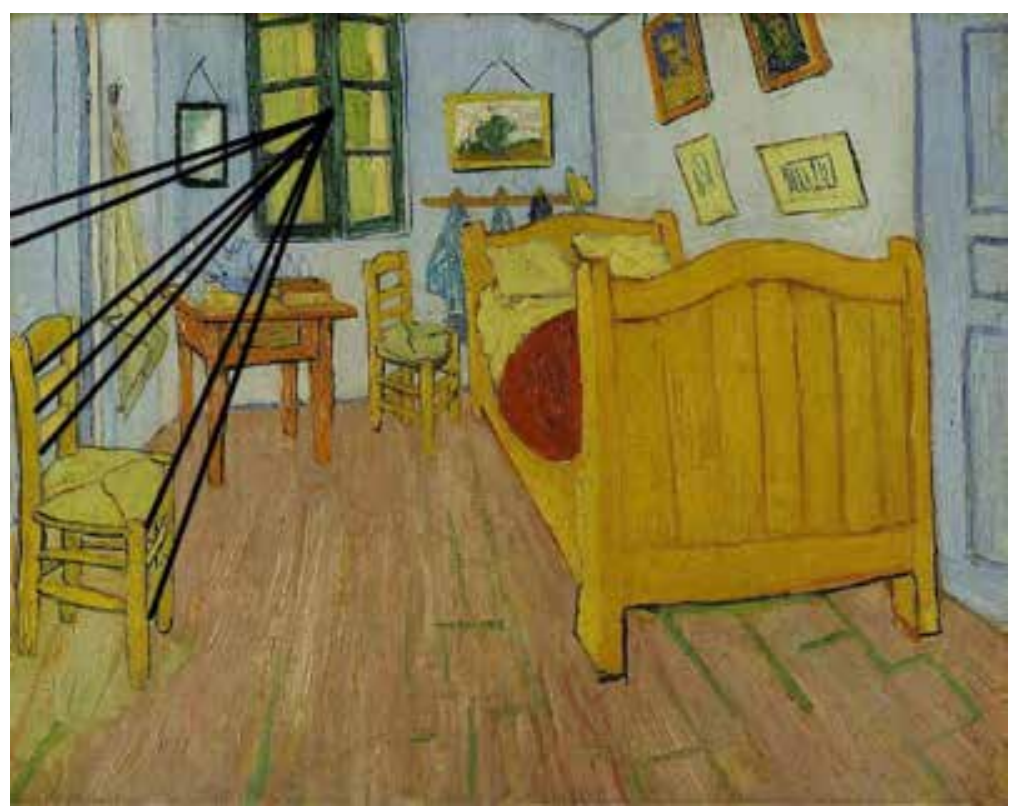

Fig. 3. Bedroom in Arles, Vincent van Gogh (1888) 


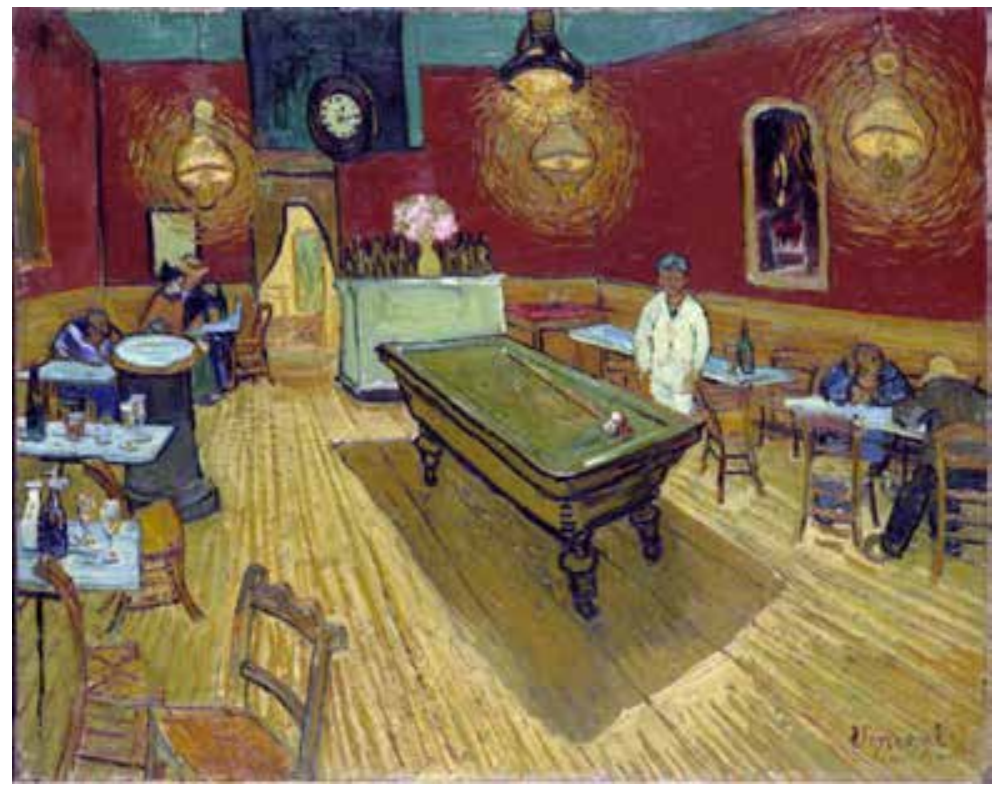

Fig. 4. Night Café, Vincent van Gogh (September 1888)

tle article on Dostoevsky, then they're the only ones that seem to me to have a more important meaning", he wrote in a letter to Theodor Van Gogh (Gasheva, 2006). In this painting, he highlights the tragic element in his perception of the reality.

Since this article is intended to research the interior images in the works by Van Gogh, the next representative painting for the internal architecture study is The Night Café.

The Night Café is a painting created by Vincent van Gogh during his stay in Arles in September 1888 . With the perimeter of $70 \times 89$ $\mathrm{cm}$, it is a chamber work. The chamber nature of the painting implies the intimacy of a dialogue with it. The composition of the painting presents the perspective space structure with one vanishing point lying in the first lamp on the left (Fig. 5). At the same time, some pieces of furniture have two vanishing points, which complies with the law of perspective. One of such two-point perspective items is the billiard table. One of the points lies in the exit from the café in the wall opposite to the viewer, with the perspective line crossing the wall and reaching the lamp figure; the second point, in its turn, lies in the empty space in the wall, and the perspective line is drawn over the café owner and the alcoholic drink bottle; then, it stretches somewhere beyond the borders of the painting.

The billiard table is the central figure of the composition, placed diagonally, from the bottom right to the upper left corner. This perspective makes an illusion of proximity of the billiard table and the chairs, which also have two vanishing points each lying on the same horizontal axis as the billiard table. The piece is full of clear vertical lines, such as corners of the room, door and window openings and clearly traced floor boards, chair backs and table legs. In their turn, the horizontal lines are highlighted by the decorative division of the walls into the yellow and red parts, the cubic structure of the room, supported by the horizontal lines on the ceiling, the rhythmic arrangement of lamps and the rectangular shape of the counter. Just like the viewer, the painter is also looking at the room from a point opposite to the café entrance door.

Generally, the lines are curved and not always carefully vetted, which indicates the emotional charge of the piece. The vague and dynamic lines together with the shadows create the effect of a transforming space. For example, on the wall with the exit door and the counter on the left side, and in the bottom left 


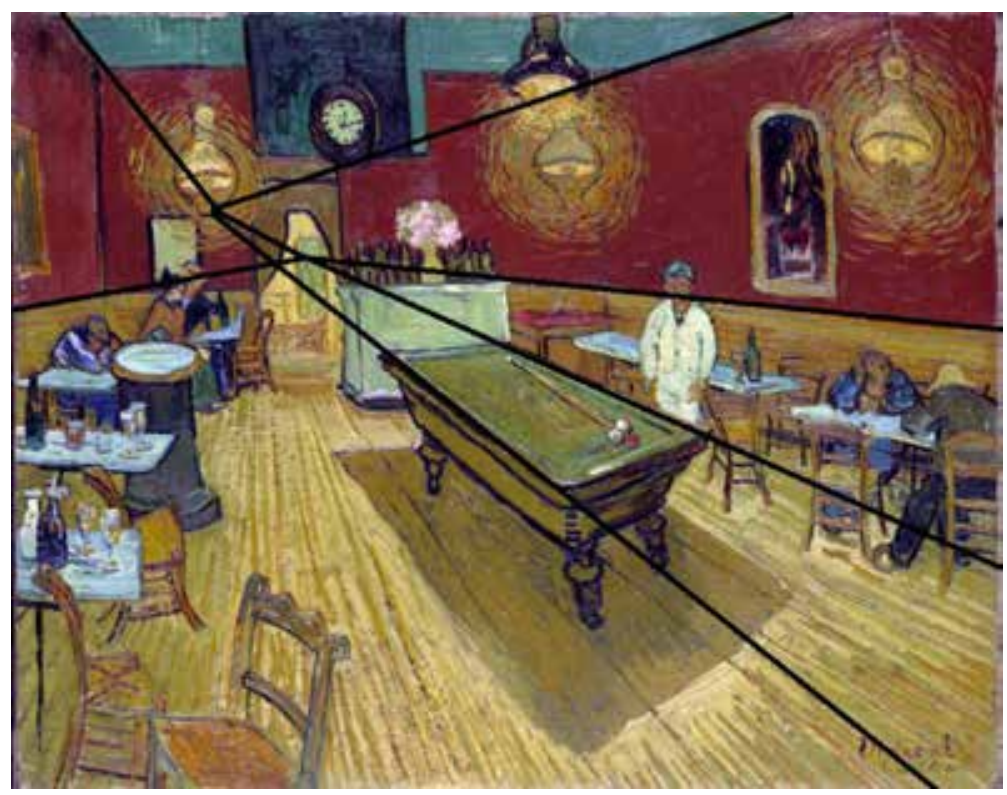

Fig. 5. The Night Café. Vincent van Gogh (September 1888)

(perspective model)

corner there are more shadows than in the opposite right corner. This arrangement of shadows creates the effect of distorted space.

The perspective structure of the painting with such a vanishing point creates the optical impression of presence inside the scene, which is also ensured by the incomplete figure of the chair facing the viewer.

The painting is oil on canvas, which is the technique that allows using some local and bright colours. Speaking of the colour, it is worth quoting the words of the author himself: "I've tried to express the terrible human passions with the red and the green. The room is blood-red and dull yellow, a green billiard table in the centre, four lemon yellow lamps with an orange and green glow. Everywhere it's a battle and an antithesis of the most different greens and reds; in the characters of the sleeping ruffians, small in the empty, high room, some purple and blue. The blood-red and the yellow-green of the billiard table, for example, contrast with the little bit of delicate Louis XV green of the counter, where there's a pink bouquet. The white clothes of the owner, watching over things from a corner in this furnace, become lemon yellow, pale luminous green",
"It's a colour, then, that isn't locally true from the realist point of view of trompe l'oeil, but a colour suggesting some emotion, an ardent temperament" (Van Gogh, 2010). In this case, the contrast is based on the combination of green, red colours and their tones; they are opposite, i.e. creating and active complementaries' opposition according to the colour theory of Johannes Itten" (Itten, 2001). This principle creates active, emotional and saturated combinations. For Vincent van Gogh, such a combination is associated with aggression.

The light colour spots' arrangement principle is found in the repeating elements of the ceiling lamps, creating a triad of light spots. The entire piece is based on the contrast of light and dark spots, which originates from the selection of the contrast, opposite colours. Yellows and greens, however, are close to each other in the colour spectrum.

This way, we see a domination of a strong diagonal line in the composition and the absence of the main horizontal and vertical axes. All of them are equally important to each other. The space is based on the linear perspective laws. The dynamic nature of the lines indicates the emotional charge of the painter. The 
rhythmic arrangement of the light colour spots is only typical for the upper part of the work. There is a colour contrast, and, according to the painter, the contrast of green and red evokes the emotion of a destructive way of life, insanity and passion.

Speaking about the anthropomorphic characters of the painting, there are the figures of the owner of the café, a man and a woman sitting by the table, a man lying over his table a couple of men bent over the table. Extrapolating the description provided by the author himself, this painting shows some "ruffians", a woman of easy virtue with her companion and the owner of the café. The selected colours present the emotions of human passions; the people in the painting also represent the passions, such as the lifestyle of a tramp, a person who has nowhere to go. Then, the person finds a shelter in a night café, where for a short while he remains in the same place. The passion of adultery is presented by the woman and the man sitting by the table. The woman is sitting by the man, with her profile turned to the viewer, while the man is looking at the viewer directly. Faced by the characters, the viewer is invited to get involved in their story. The man lying over the table is half-facing the viewer, but his posture is closed, revealing his tiredness. As for the pair of men by the table, they are facing each other; one of them is half-facing the viewer, and the other is sitting with his back to us. The owner of the café is maximally open, standing upright. We may conclude that the characters are open, intending to get the viewer involved in the dimension of the painting, actively communicating with him. Their clothes deserve a special mentioning; they are mostly blue, which is a cold colour.

The non-anthropomorphic figures of the painting are also important for the analysis. It is worth studying the central billiard table with the billiard balls on it. The table is green and monumental, aligned with the overall perspective structure; on the table surface, there is a cue ball used to strike the other balls. There are no players involved in the game at the moment, and three balls are arranged in the way that indicates the end of the game. The cue stick is pointing away from the viewer. Combined with the diagonal dynamics of the composition, the game represents the move of a person about to make a choice. In this case, one can leave the Night Café through the virtual space of the game offered to the viewer. In the theory of art, the dynamic diagonal flow from the upper left corner to the bottom right means a descend. The diagonal is bidirected, finishing in the bottom right corner on one side and pointing at the exit door on the other, as though inviting the viewer to walk this way. Near the billiard table, there stands the owner of the café, making an inviting gesture. The combination of the billiard table, the owner figure and the green bottle near the owner is a temptation for the viewer.

The figure of the clock is hanging over the figure of the counter, clearly showing the time, quarter past midnight, which is the middle of the night, the turn of the day. The clock is placed in the same space as the exit, signifying the state of transition.

Such elements as paintings on the walls, the vase with flowers, the counter, and utensils bear a secondary meaning to the interpretation of the piece and the primary meaning for the contrast of colours.

The painting presents a tragic state of man the viewer is invited into with a number of artistic techniques, especially with the linear perspective solution and the vanishing point shifted to the left, creating the illusion that the viewer has just entered the room. A big monumental object in the foreground, which is, in this case, the billiard table, combined with the other characters of the painting, invite the viewer to commit a tragic deed destructive to the soul. The Night Café exit space is diagonal, keeping the opportunity to leave this tragedy, this passion, this aggressive atmosphere and the way of life that kills both the physical and spiritual components of man. The primary element of the painting is the colour, and, particularly, the conflict of the opposite, contrast colours and the dynamic lines for a more vivid expression of the emotional passion and tragedy of this piece.

We may conclude that The Night Café by Vincent van Gogh lures the viewer into the 
tragic world of passions and emotions, offering him an emotional experience and a way out of it. It is an offer to walk the way of desperation and find a spiritual relief from the horrible human passions.

This arrangement of the internal architectural space promotes the effect of presence in the action depicted in the piece of art.

\section{Interior of a Restaurant in Arles,}

\section{Vincent van Gogh (August 1888)}

Unlike Bedroom in Arles representing personal space, Interior of a Restaurant in Arles and The Night Café are dedicated to public spaces. This work of art still remains understudied, and, therefore, needs to be considered. It is not a well-known painting, not an object of attention of the art critics. It is usually mentioned among other pieces of the interior genre.

Dated with August 1888, Interior of a Restaurant in Arles belongs to the series of paintings created by Van Gogh in Arles. It is not big in size, which implies the intimacy of interaction. The format of the painting is almost square (with the width slightly bigger than the length), suggesting a static and fixed presentation of the scene rather than a narration of subsequent actions.
The impersonal space interior represents the specificity of social relations, the social structure of the society etc. What is the interior of a restaurant in Arles like and what aspects of the social system does it represent?

The interior of the restaurant is simple, just like the plot of this piece of art. It is almost ascetic with five long and narrow tables with light surfaces arranged in diagonal rows. The first three tables are not occupied: the chairs are pushed in, there is hardly any tableware except for several water and wine bottles and a glass. At the farther tables, there are many people absorbed in their meal, there are flowers on the tables and the walls are decorated with paintings. A woman is walking towards the centre of the table.

The composition (Fig. 7) of the painting relies upon the diagonal lines drawn from the bottom right corner visualized through the narrow and long tables of the restaurant; the vanishing point of these lines lies beyond the borders of the painting, visually taking the onlooker outside. The vertical lines of the glassware, vases and figures of the visitors keep the composition static.

The diagonal lines of another direction (Fig. 8) are formed by two groups of charac-

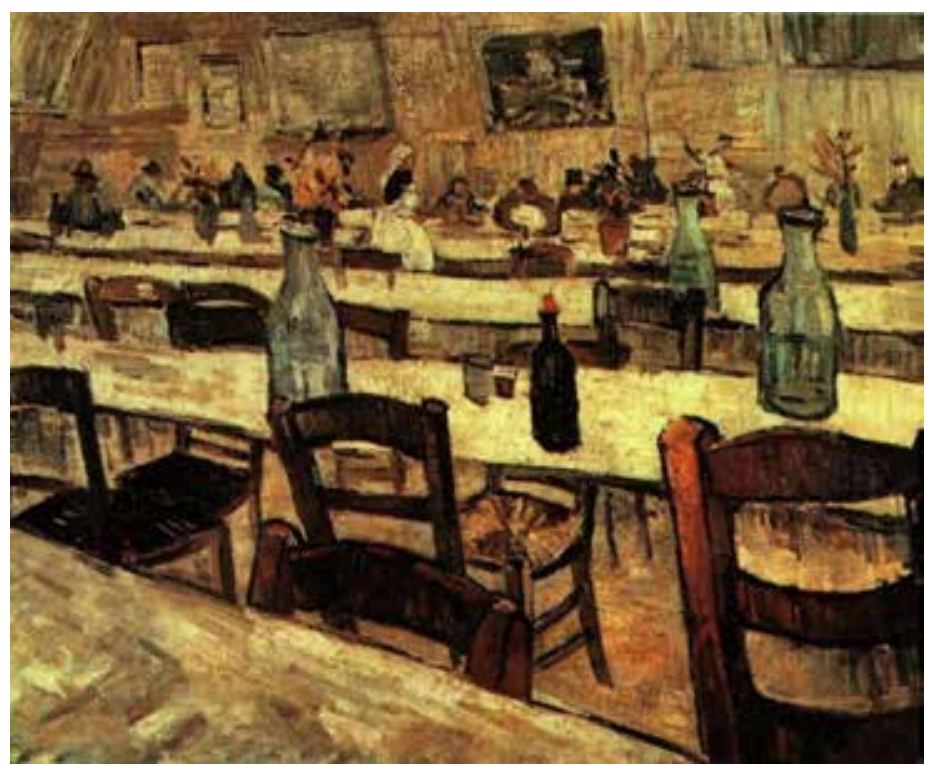

Fig. 6. Interior of a Restaurant in Arles, Vincent van Gogh (August 1888) Oil, canvas; $54^{*} 64 \mathrm{~cm}$ 


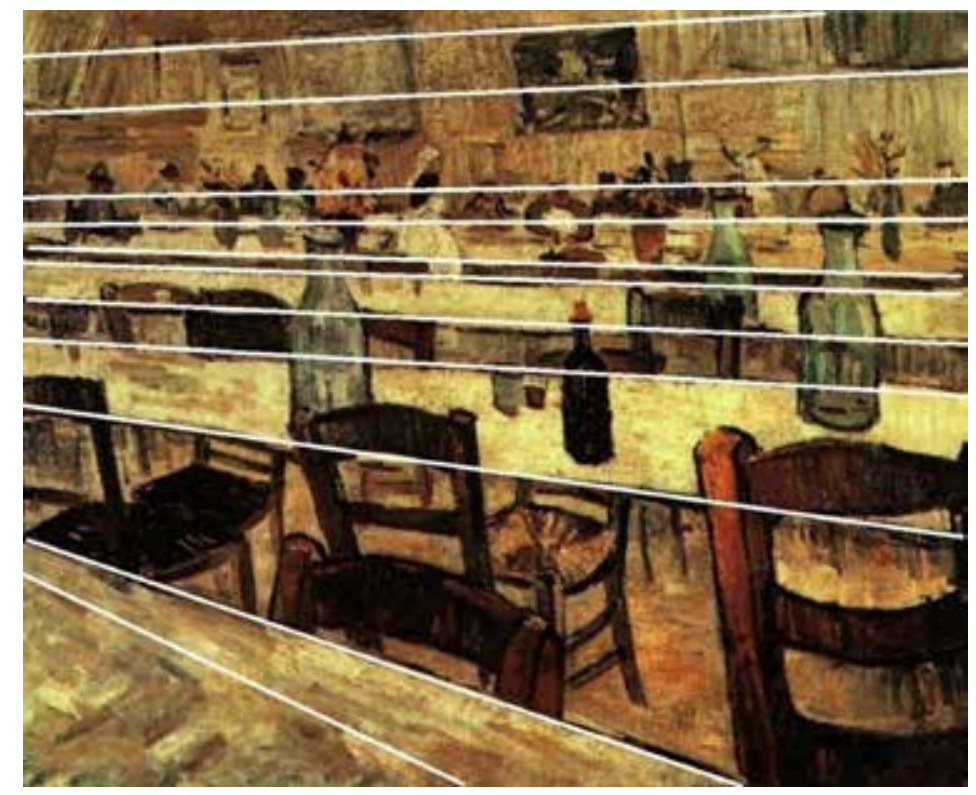

Fig. 7. Interior of a Restaurant in Arles, Vincent van Gogh (August 1888)

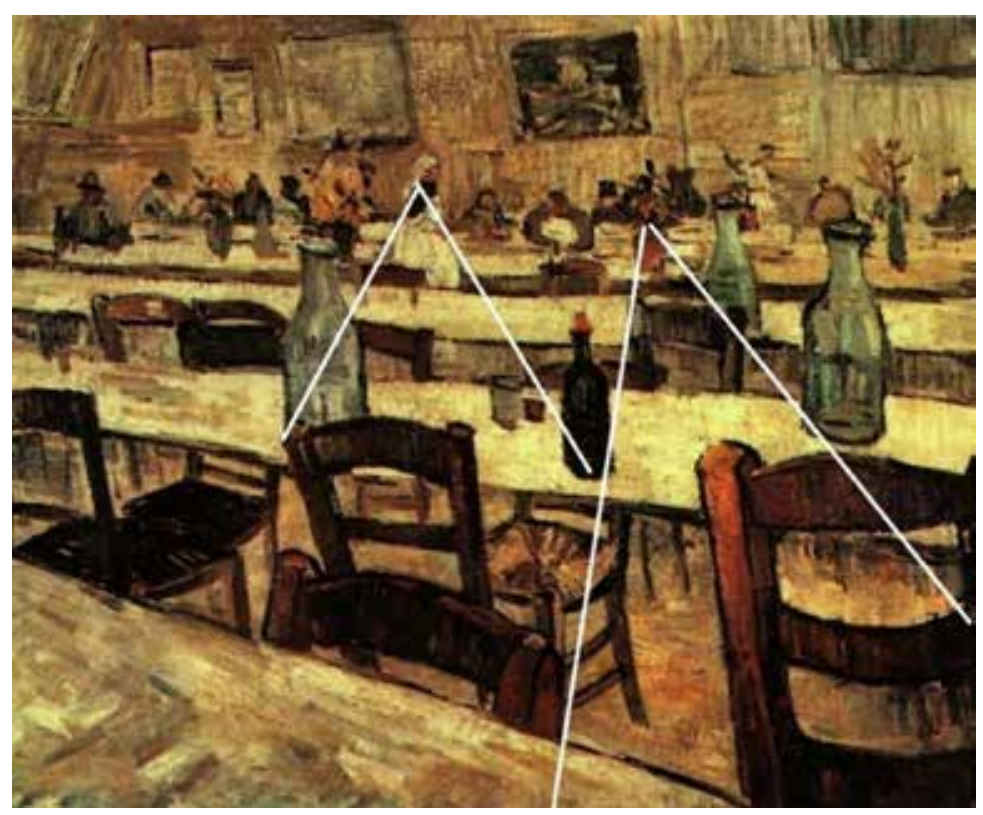

Fig. 8. Interior of a Restaurant in Arles, Vincent van Gogh (August 1888)

ters: 1) the vases standing on the remote tables, with the vase being the vanishing point; 2) the wine and water bottles and the walking woman. These triangles of the perspective lines guide the viewer's look and get him optically involved in the composition. These compo- sition lines create a borderline position of the viewer: though involved in the painting, at the same time he is guided to leave its borders by the composition lines.

The scale of colours is based on the contrast principle: the light-ochre and dark brown 
spots are placed side by side, maximizing the perception of both colour tones: the blue and reddish shades, the rare green splashes coming up one after another, highlighting each other, i.e. creating complementary pairs in accordance with the colour theory (Itten, 2001). The ochre and dark-brown colours are mostly horizontally arranged with the blue, red, and green creating the vertical colour highlights. However, the background of the painting appears to be richer in terms of colour.

The foreground is represented by a part of an empty table with no tableware or dishes; the viewer is offered a point of view of another visitor of the restaurant. Farther away, we see two unoccupied light-coloured long and narrow tables, with only empty bottles standing on them; there are no vases with flowers and the chairs are pushed in. At the second table, there are some signs of a recent visitor: a bottle of wine and a glass by its side.

The third one looks the least welcoming for visitors: with only one water bottle for the entire table, less chairs and no flowers it looks deserted. The fourth and the fifth tables almost merge into one. The gap between them is hardly visible, and the visitors are sitting close to each other, making the impression of a dense crowd from one border of the painting to the other. These two tables are decorated with vases of flowers, and there are paintings on the wall behind them.

The anthropomorphic characters are outlined in a very general way, with wide strokes of local colours, united into a group of characters. The only individualized character is the walking woman; standing out with her manner of motion, she draws attention with the verticality of her figure, the dynamics and direction of her walk, and clearer traced clothes reminding the uniform of a nurse.

The contrast light-coloured surface of the tables stands out in the background, perceived as a separator of the space. The first three rows are a lifeless territory with no people or any associated signs, like water bottles, tableware, or flowers. If there was a visitor at the second table, he would have been alone, and the presence of another person would not bring more life to this part of the space. This is a zone of alienation. At the same time, the fourth and the fifth tables are the epicentre of the restaurant life. The background is bustling with activity: the visitors absorbed in their meal, the walking woman, the flower pots, and paintings on the wall. Importantly, the flowers found around the restaurant are planted in pots, which is more typical for a homely interior. Due to her resemblance to a nurse, the woman may act as a symbol of life, salvation, and humanity.

In this piece of art, the interior is a reflection of the social and psychological conditions. Visually united by the table they are sitting at, the people are shown as a dense mass; the pot plants contribute to the image of community, unity, and life. At the same time, the first tables draw the picture of loneliness, alienation, and emptiness. The light-ochre tables standing out in the overall colour scheme remind of crossroads, offering the viewer to choose between joining the others and being alone.

\section{Conclusion}

The artistic studies of Vincent van Gogh belong to the post-impressionism trend, which declares the principal significance of the author's personal manner and representation of his individual world outlook. Just like other representatives of the trend, Van Gogh relied upon the achievements of impressionism and foreign art traditions, such as Japanese graphics, transformed by his subjective visual perception. The painting technique of Van Gogh is easy to recognize with the short dynamic strokes; colour prevailing over shape, distorting some elements of space. Together with colours, lines are used to shape up the saturated emotional charge of the paintings, expressing the psychological state of the author. The emotionally expressive language of the painter was used to manifest a number of spiritual and moral problems.

The review of the published studies showed how thoroughly the works of Van Gogh have been considered by representatives of different branches of knowledge and with a number of interdisciplinary approaches. The academic interest to the art of this painter is intensively developing and does not seem to fade: the researchers look upon the interdependence of 
the biography of the painter and the features of his individual techniques, the innovation of his painting manner, the technical aspects of painting, the symbolism and the influence Van Gogh made on his successors etc. We may notice a gradual increase in the number of studies intended to present the complete image of the artist to replace the picture of an artistically gifted man with a hard destiny and mental illnesses. The comprehensive studies of the painter's life and works attract many researchers of the early $21^{\text {st }}$ century.

Since the earliest periods, interior paintings have played a significant role in the art of Van Gogh. The architectural space and interior decorations were more than a formal picture of the material world, but acted as symbols for the psychological states and emotional dispositions. In his paintings, Vincent van Gogh turns to both personal and public interiors. However, due to their almost square format and chamber size, the works depicting public spaces are more likely to be perceived as personal, imposing a more intimate way of interaction. The philosophic and artistic analysis of the selected works showed that the interiors in the works by Van Gogh present the space of transformation. An ordinary bedroom is given a status of a sacral place where the mystery of creation takes place. A café acts as a place where one can contemplate over the finiteness of existence full with complex emotions, but, at the same time, this is a place where one can transform by releasing the passions burdening him. A piece of art may also throw the viewer into a hard psychological dilemma between the loneliness one is inclined to and the desire to join the society, as offered by Interior of a Restaurant in Arles. The arrangement of the composition and the colour system tunes the viewer to a certain emotional state; the pieces painted within three months of 1888 manifest the absolutely opposite states: one creates the feeling of joy and the experience of happiness; the other evokes the feeling of tragedy and hopelessness, and the third one represents the feeling of loneliness and alienation. However, in the complementary colours, types of lines and optic distortions of the linear perspective, the viewer can always find the way to escape these situations and leave. The interior spaces in the paintings by Van Gogh do not dominate over the viewer; they offer him to make a choice of his own.

\section{References}

Amosova, A.A., Koptseva, N.P., Sitnikova, A.A., Seredkina, N.N., Zamaraeva, Iu.S., Kistova, A.V., Reznikova, K.V., Kolesnik, M.A., Pimenova, N.N. (2019). Ethnocultural Identity in the Works of Krasnoyarsk Artists. In J. Sib. Fed. Univ. Humanit. soc. sci., 12(8), 1524-1551. DOI: 10.17516/1997-1370-0463

Andronova, I.O. (2014). Inter'er kak prostranstvo, napolnennoe magiey i nastroeniem na primere zhivopisi SShA i Rossii XX veka [Interior as a Space Filled with Magic and Mood, Based on Painting of the USA and Russia]. In Dostizheniia vuzovskoi nauki [Achievements of College Science], 8, 28-33.

Arnold, W.N., Loftus, L.S. (1991). Xanthopsia and van Gogh's yellow palette, 5, (5), 503-510.

Avdeeva, Iu.N., Degtiarenko, K.A., Metliaeva, S.V., Pchelkina, D.S., Fil'ko, A.I., Koptseva, N.P., Shpak, A.A. (2019). Dynamics of Krasnoyarsk Urban Space in the Early $21^{\text {st }}$ century. In J. Sib. Fed. Univ. Humanit. soc. sci., 12(6), 953-974. DOI: 10.17516/1997-1370-0434.

Balan, M.V. (2007). Panoramnyi peizazh v tvorchestve Van Goga [Panoramic Landscape in the works of Van Gogh]. In Trudy Sankt-Peterburgskogo gosudarstvennogo universiteta kul'tury i iskusstv [Proceedings of the St. Petersburg State University of Culture and Arts], 176, 49-69.

Balan, M.V. (2008). Evoliutsiia obraza v portretakh Van Goga [Evolution of Image in the Portraits by Van Gogh]. In Trudy Sankt-Peterburgskogogo sudarstvennogo universiteta kul'tury i iskusstv [Proceedings of the St. Petersburg State University of Culture and Arts], 178, 15-22.

Beloshapkina, Ia. (2013). Ot nadezhdy k otchaianiiu [From Hope to Despair]. In Iskusstvo [Art], 3, 22-39.

Benezech, M., Addad, M. (1997). Van Gogh, the Stigmatized Man of the Society. In Ann. Med. Psychol., 142, (9), 1161-1171. 
Berggren, L. (1997). Drugs and Poisons in the Life of Vincent van Gogh. In Sven. Med. Tidskr., 1, (1), 125-134.

Blumer, D. (2002). The Illness of Vincent van Gogh. In Am. J. Psychiatry, 159 (4), 519-526.

Brettell, R.R. (1986). Van Gogh's Bedrooms at Arles: the problem of priority. In Museum Studies, 12 (2), 137-151.

Chudov, I (2018). Postimpressionisty [Post-impressionists]. Moscow, AST, $160 \mathrm{p}$.

Dichenko, E. (2015). Khudozhnik v 100 kartinakh. Vinsent Van Gog [Artist in 100 Paintings. Vincent van Gogh], Moscow, 96 p.

Dmitrieva, N.A. (1984). Van Gog: Chelovek i khudozhnik [Van Gogh: Man and Artist], Moscow, 400 p.

Drobysheva, M.M. (2014). Obraz genial'noi lichnosti Vinsenta Van Goga v predstavleniiakh rossiian: sravnitel'nyi analiz v raznykh sotsial'nykh gruppakh [The Image of the Genius Personality of Vincent van Gogh Through the Eyes of Russians: Comparative Analysis Between Different Social Groups]. In Privolzhskii nauchnyi vestnik [Volga Scientific Bulletin], 11-2(39), 111-117.

Dvoretskaia, E.A. (2016). Van Gog. Zheltye tsvety [Van Gogh. Yellow Flowers]. In Sbornik statei Mezhdunarodnoi nauchno-prakticheskoi konferentsii molodykh uchenykh, posviashchennaia 65-letiiu FGBOU VO Penzenskaia GSKHA [Collection of Articles of the International Scientific and Practical Conference of Young Scientists Dedicated to the $65^{\text {th }}$ Anniversary of FSBEI HE Penza State Agricultural Academy]. Penza, 207-209.

Elina, E.A. (2019). Sposoby khudozhestvennogo vospriiatiia v iazykovoi forme (na primere interpretatsii kartin V. Van Goga) [Methods of Artistic Perception in Linguistic Form (Based on Interpretations of Paintings by V. van Gogh)]. In V sbornike: Polilog i sintez iskusstv: istoriia i sovremennost', teoriia i praktika. Epokhi-stili-zhanry Materialy II Mezhdunarodnoi nauchnoi konferentsii [In the collection: Polylogue and Synthesis of Arts: History and Modernity, Theory and Practice. Epochs - Styles - Genres. Proceedings of the $2^{\text {nd }}$ International Scientific Conference], St. Petersburg, 39-41.

Heinich, N. (2014). Slava Van Goga. Opyt antropologii voskhishcheniia [Glory of Van Gogh: An Anthropology of Admiration]. Moscow, V-A-C press, $384 \mathrm{p}$.

Filippova, S.A. (2014). Byt' samim soboi: psikhologicheskii portret Vinsenta Van Goga [Be Yourself: A Psychological Portrait of Vincent Van Gogh]. In Mezhdunarodnaia nauchno-prakticheskaia konferentsiia «Chelovek. Iskusstvo. Vselennaia» [International Scientific and Practical Conference "Human. Art. The Universe"]. Sochi, 288-304.

Gasheva, N.N. (2006). Vzaimodeistvie khudozhestvennykh kontseptsii F.M. Dostoevskogo i V. Van Goga [Interaction of the Artistic Concepts of F. M. Dostoyevsky and V. van Gogh]. In Vestnik NovGU, 36, 4 p.

Golenkov, A.V. (2011). Vinsent Van Gog: patograficheskii ocherk [Vincent van Gogh: A Pathographic Essay]. In Meditsinskaia psikhologiia v Rossii [Medical Psychology in Russia], 1. available at: http://medpsy.ru

Gordeeva, E. (2017). 8 faktov o Van Goge ili prichiny poliubit' khudozhnika [Eight Facts about Van Gogh or Reasons to Love the Artist]. In Beatris Zhurnal [Beatrice Magazine], available at: http://beatricemagazine.com/8-facts-about-van-gogh/

Gordeeva, M. (2009). Velikie khudozhniki. Vinsent Van Gog [Great Artists. Vincent van Gogh], Moscow, $48 \mathrm{p}$.

Groom, G.L. (2016). Van Gogh's Bedrooms. In Yale University Press, 166 p.

Harold, P., Blum, M.D. (1956). Van Gogh's Chairs. In American Imago, 13, (3), 307-311, 313-318.

Heelan, P. (1983). Space-Perception and the Philosophy of Science. Berkeley: University of California Press, $383 \mathrm{p}$.

Hendriks, E. et al. (2011). A Comparative Study of Vincent van Gogh's Bedroom Series, In Studying Old Master Paintings: Technology and Practice. In The National Gallery Technical Bulletin 30th Anniversary Conference Post Prints, Archetype, 237-243.

Hulsker, J. (1988). Bedroom Problems. In Simiolus: Netherlands Quarterly for the History of Art, 18 (4), 257-261.

Ievleva, A.A., Khrapugina, S.A. (2019). Van Gog i ego vklad v razvitie iskusstva [Van Gogh and His Contribution to the Development of Art]. In Razvitie lichnosti sredstvami iskusstva [Personal Development Through Art], Saratov, 180-186. 
Illouz, J.-N. (2005). The manifesto symbolists [Les manifestes symbolists]. Paris, Littérature. 139, 93-113. Itten, J. (2001). Iskusstvo formy [Art of Forms]. Moscow, IzdatelD.Aronov, 138 p.

Karimov, D.A., Serdiuchenko, V.M., Volkova, P.S. (2018). Van Gog. "Bashmaki”: opyt interpretatsii [Van Gogh. Sabatons: Interpretation Experience]. In Aktual'nye problemy sovremennogo sotsiokul'turnogo prostranstva. Materialy Mezhdunarodnoi nauchno-prakticheskoi konferentsii [Actual Problems of the Modern Sociocultural Space. Proceedings of the International Scientific and Practical Conference], 166-169.

Kas'ianov, A. (2019). Poiski Vinsenta. Stil' i tekhnika Van Goga [Searching for Vincent. Van Gogh Style and Technique], available at: https://artchive.ru/publications/1934 Poiski_Vinsenta_Stil_i_tekhnika_Van_Goga

Kharybina, M.V. (2019a). Dialog kul'tur Rossii i Evropy rubezha XIX i XX vekov (na primere tvorchestva F. M. Dostoevskogo i V. Van Goga) [Dialogue of Cultures of Russia and Europe at the Turn of the 19 and $20^{\text {th }}$ Centuries (Based on Works of F. M. Dostoevsky and V. van Gogh)]. In Materialy Mezhdunarodnoi nauchno-prakticheskoi konferentsii "Dialog kul'tur i tsivilizatsii" [Proceedings of the International Scientific and Practical Conference "Dialogue of Cultures and Civilizations"], 210-216.

Kharybina, M.V. (2019b). Problematika "dialoga kul'tur": tvorchestvo V. Van Goga I khudozhestvennaia kontseptsiia L.N. Tolstogo [Problems of the "Dialogue of Cultures": Work of V. Van Gogh and the Artistic Concept of L.N. Tolstoy]. In Tezisy dokladov ezhegodnoi konferentsii Studencheskogo nauchnogo obshchestva MGLU [Abstracts of the Annual Conference of the Student Scientific Society of MSLU]. Moscow, Moscow State Linguistic University, 39-40.

Kim, J.H., Yoon, J.E. (2012). A Study on the Spatial Characteristic Reflection on Vincent van Gogh's' The Bedroom at Arles, 21 (5): 244-253.

Kokurina, E.M. (2006). Marina Tsvetaeva I Vinsent Van Gog. Zhazhda Solntsa [Marina Tsvetaeva and Vincent van Gogh. Longing for the Sun]. In Vestnik Universiteta Rossiiskoi Akademii Obrazovaniia [Bulletin of the University of the Russian Academy of Education], 2, 54-59.

Koptseva, N., Reznikova, K., Razumovskaia, V. (2018). The Construction of Cultural and Religious Identities in the Temple Architecture. In Journal of Siberian Federal University. Humanities \& Social Sciences, 7 (11), 1021-1082.

Koptseva, N.P., Luzan, V.S., Razumovskaia, V.A., \& Kirko, V.I. (2017). The Content Analysis of the Russian Federal and Regional Basic Legislation on the Cultural Policy. In International Journal for the Semiotics of Law-Revue internationale de Sémiotique juridique, 30(1), 23-50.

Kotliar, E.R., Emiruseinova, F.S. (2017). Osobennosti unikal'noi tekhnologii zhivopisi Vinsenta Van Goga [Features of Vincent Van Gogh's Unique Painting Technology]. In Tavricheskii nauchnyi obozrevatel' [Tauride Science Columnist], 10 (27), 85-89.

Kuzova, N.V. (2015). Zhizn' i Tvorchestvo Vinsenta Van Goga [Life and Work of Vincent van Gogh]. In Molodoi uchenyi: Iskusstvovedenie [Young Scientist: Art Criticism], 16 (96), 462-465.

Lee, T.C. (1981). Van Gogh's vision. Digitalis intoxication, JAMA, 245, (7), 727-729.

Lemke, S., Lemke, C. (1994). The psychiatric disease of Vincent van Gogh, Nervenarzt, 65, (9), 594-598.

Lugantsev, D.N. (2017). Osobennosti grafiki Van Goga [Features of Van Gogh's graphics]. In Materialy mezhdunarodnogo nauchnogo foruma obuchaiushchikhsia "Molodezh' v nauke i tvorchestve" [Materials of the International Scientific Forum of Students "Youth in Science and Art"]. Gzhel, Gzhel State University, 86-89.

Makhlina, S. (2009). Semiotika kultury povsednevnosti [Semiotics of Everyday Life Culture]. St.Petersburg, Alteyia, $232 \mathrm{p}$.

Margolis, J. (2002) Patrick Heelan's Interpretation of Van Gogh's "Bedroom in Arles". In Hermeneutic Philosophy of Science, Van Gogh's Eyes, and God. Boston Studies in the Philosophy and History of Science, Springer, Dordrecht, $225 \mathrm{p}$.

Mehlum, L. (1996). Suicidal Process and Suicidal Motives. Suicide Illustrated by the Art, Life and Illness of Vincent Van Gogh. In Tidsskr. Nor. Laegeforen, 116 (9), 1095-1101.

Montejo Gonsalez, A.L. (1993). Implication of Lead Poisoning in Psychopathology of Vincent van Gogh. In Act.Luso Esp. NeuroPsiquiatr. Cienc.Afines, 25 (5), 309-326. 
Morrant, J.C. (1993). The Wing of Madness: the Illness of Vincent van Gogh. In Can. J. Psychiatry, $38,(7), 480-484$.

Murina, E. (1978). Van Gog [Van Gogh]. Moscow, Nauka. 382 p.

Najfi S. (2016) Van Gog [Van Gogh]. V. 2, Saint Petersburg, Azbuka, 668 p.

Perruchot, H. (1987). Zhizn' Van Goga [Life of Van Gogh]. Moscow, Raduga, 383 p.

Plastova, T.Iu. (2012). Vinsent Van Gog - Arkadii Plastov: paradigma bytiia i zhivopisnaia traditsiia [Vincent Van Gogh - Arkady Plastov: The Paradigm of Being and the Painting Tradition]. In Vestnik MGKhPA [Bulletin of Moscow State University of Arts and Industry]. Moscow, Stroganov Moscow State University of Arts and Industry, 1 (2), 90-97.

Poliakova, E.A., Motova, T.V. (2019). Van Gog “Zvezdnaia noch"”. Istoriia odnogo shedevra [Van Gogh "Starry Night". The History of a Masterpiece]. In Perspektivy razvitiia tekhnologii obucheniia izobrazitel'nym distsiplinam $v$ VUZakh [Prospects for the Development of Art Teaching Technology of Universities]. Penza State University of Architecture and Construction, 31-37.

Puchkova, A.Iu. (2016). Tvorchestvo Vinsenta Van Goga i ego vklad v iskusstvo [Works of Vincent van Gogh and His Contribution to Art]. In Sbornik statei Mezhdunarodnoi nauchno-prakticheskoi konferentsii "Novye informatsionnye tekhnologii v nauke novogo vremeni" [Proceedings of the International Scientific and Practical Conference "New Information Technologies in Science of the New Time"]. Volgograd, NITs Aeterna, 274-275.

Rahe, R.H. (1990). Psychosocial Stressors and Adjustment Disorder: van Gogh's Life Chart Illustrates Stress and Disease. In J. Clin. Psychiatry, 52, 13-19.

Rodionov, N.S. (2017). Istoriia razvitiia khudozhestvennoi lichnosti Vinsenta Van Goga [The History of the Development of the Artistic Personality of Vincent Van Gogh]. In Materialy VIII Mezhdunarodnoi nauchno-prakticheskoi konferentsii "Nauka i obrazovanie" [Proceedings of the $8^{\text {th }}$ International Scientific and Practical Conference "Science and Education"]. Moscow, Pero Publishing House, 12-16.

Rovenko, E.V. (2016). Vinsent Van Gog i Odilon Redon kak posledovateli Ezhena Delakrua. Printsipy "omuzykalivaniia" zhivopisi [Vincent can Gogh and Odilon Redon as Successors of Eugene Delacroix. Painting "Musicization" Principles]. In V prostranstve smyslov [In the Space of Meanings], 447-456.

Runyan, W.M. (1981). Why did Van Gogh Cut Off His Ear? The Problem of Alternative Explanations in Psychobiography. In J. Pers. Soc. Psychol., 40, (6), 1070-1077.

Sachkov, I.N., Chistiakov, M.A. (2019). Mir kul'tury: iskusstvo, nauka, obrazovanie [The World of Culture: Art, Science, Education]. In Sbornik nauchnykh stateii i tvorcheskikh rabot [A Collection of Scientific Articles and Creative Works]. Chelyabinsk, Tchaikovsky South Ural State University, 8, 109-117.

Saggio, A. (2011). The Bedroom by Vincent van Gogh: Symbols, Autobiographical Images and Perspective Distortions. In Disegnare idee immagini-ideas images, 22 (43), 12-25.

Sannikova, E. (2019). Simvolicheskii kapital Vinsenta Van Goga v kontekste kontseptsii ekonomik $i$ kul'tury D. Trosbi [The Symbolic Capital of Vincent van Gogh in the Context of Cultural Economics of D. Trosby]. In Universum: Filologiia i iskusstvovedenie [Universum: Philology and Art Criticism], 3(60), available at: http://7universum.com/ru/philology/archive/item/7061

Savichev, A. (2016). Znakomstvo s tvorchestvom Vinsenta Van Goga [Acquaintance with the Work of Vincent Van Gogh]. In Materialy Mezhdunarodnogo nauchnogo foruma obuchaiushchikhsia 'Molodezh' v Nauke i tvorchestve" [Proceedings of the International Scientific Forum of Students "Youth in Science and Art']. Gzhel State University, 611-613.

Scillia, D.G. (2004). Vincent Van Gogh's Five Bedrooms at Arles: An Analysis of Creative Copies. In Imaginatio Creatrix, Springer, Dordrecht, 461-476.

Shul'ts, S.A. (2018). V. Van Gog - K. Gamsun - M. Khaidegger (k voprosu ob ontologicheskom statuse iskusstva) [Van Gogh - K. Gamsun - M. Heidegger (on the Ontological Status of Art)]. In Vestnik $R G G U$. Seriia: Literaturovedenie. Iazykoznanie. Kul'turologiia [Bulletin of the Russian State Humanitarian University. Series: Literary Studies. Linguistics. Culturology], 135-140. 
Sokolov, M. (1986). Inter'er v zerkale zhivopisi: zametki ob obrazakh i motivakh v russkom i sovetskom iskusstve [Interior in the Mirror of Painting: Notes on Images and Motifs in Russian and Soviet Art]. Moscow, Sovetskii khudozhnik, $228 \mathrm{p}$.

Stoian, S.P. (2015). Zapadnoevropeisrii simvolizm kak khudozhestvennoe napravlenie: kul'turno-philosophsie determinanty [Western European symbolism as an art direction: cultural and philosophical determinants]. In Aktual'nye problemy gumanitarnykh nauk [Actual problems of the humanities and natural sciences], 2(73), 221-225.

Stoun, I. (1988). Zhazhda zhizni [Longing for Life]. Moscow, Pravda Publishing House, 480 p.

Stroeva, O.V. (2014). Van Gog i fenomen razmnozheniia obrazov v sovremennoi kul'ture [Van Gogh and the Phenomenon of Image Reproduction in Modern Culture]. In Nauka televideniia [Science of Television], 11, 157-164.

Throsby, Devid. (2013). Ekonomika i kul'tura [Economics and Culture], Moscow, Higher School of Economics Publishing House, $254 \mathrm{p}$.

Trofimova, T.B. (2009). I. Turgenev i L. Tolstoi v pis'makh Vinsenta Van Goga [I. Turgenev and L. Tolstoy in letters of Vincent Van Gogh]. In Spasskii vestnik [Spassky Newsletter]. 16, 121-126.

Uolleis, R. (1998). Mir Van Goga [Van Gogh World]. Moscow, Terra Publishing House, 192 p.

Van Gogh, V. (2001). Pis'ma [Letters]. St. Petersburg, Azbuka, 848 p.

Van Gog, V. (2018). Pis'ma k bratu Teo [Letters to Brother Teo]. Moscow, AST, 477 p.

Van Tilborgh, L. et al. (2012). Weave Matching and Dating of van Gogh's Paintings: An Interdisciplinary Approach. In The Burlington Magazine, 154 (1307), 112-122.

Veimarn, B.V. et al. (1965). Vseobshchaya istoriya iskusstv. T. 6. Iskusstvo 20 veka. Chast 1 [The universal history of art. T. 6. Art of the 20th century. Part 1]. Moscow, Iskusstvo, 480 p.

Ward, J.L. (1976). A Re-Examination of Van Gogh's Pictorial Space. In The Art Bulletin, 58 (4), 593 604.

Weissman, E. (2008). Vincent van Gogh (1853-1890): the Plumbic Artist. In J. Med. Biogr., 16, (2), 109-117.

Zharina, O.Iu. (2019). Van Gog: v chem genii etogo khudozhnika? [Van Gogh: What is the Genius of This Artist?] In Sbornik materialov mezhdunarodnoi nauchno-prakticheskoi konferentsii. Kul'tura i iskusstvo [Proceedings of the International Scientific and Practical Conference. Culture and art], Krasnodar, 55-57. 


\title{
Архитектурное пространство \\ в произведениях Винсента Ван Гога
}

Ю.Н. Авдеева, К.А. Дегтяренко, М.А. Колесник,

Н.П. Копцева, Д.С. Пчелкина, А.А. Шпак

Сибирский федеральный университет

Российская Федерация, Красноярск

\begin{abstract}
Аннотация. В статье представлен обзор основных концептуальных положений постимпрессионизма с целью определения художественного и социокультурного контекста творчества Ван Гога и анализ исследовательской литературы о его творчестве, демонстрирующий многообразие подходов к изучению наследия художника. Статья содержит анализ трех произведений Винсента Ван Гога, созданных в 1888 году: «Спальня в Арле», «Интерьер ресторана в Арле» и «Ночное кафе». Эти произведения, относящиеся к одному периоду творчества художника, выбраны для исследования того, как Ван Гог через построение иллюзорного внутреннего архитектурного пространства передает разного рода психологические состояния и репрезентирует субъективную картину мира. Статья содержит результаты философско-искусствоведческого анализа указанных произведений художника, визуализирующих личное и общественное пространство, выводы о значении и роли интерьерного жанра в творчестве Винсента Ван Гога.
\end{abstract}

Ключевые слова: Ван Гог, живопись, постимпрессионизм, произведение искусства, трагизм, эпистолярное наследие, символический капитал произведения, интерьер, внутреннее архитектурное пространство, композиция.

Научная специальность: 17.00.09 - теория и история искусства; 24.00.01 - теория и история культуры. 